\title{
GAMBARAN KECERDASAN EMOSIONAL DAN PRESTASI BELAJAR PADA SISWA NEGERI XI MANADO
}

\author{
${ }^{1}$ Gesti alfiah \\ ${ }^{2}$ H.Opod \\ ${ }^{2}$ J.S.V. Sinolungan
}

\author{
${ }^{1}$ Kandidat SKRIPSI Fakultas Kedokteran Universitas Sam Ratulangi Manado \\ ${ }^{2}$ Bagian Psikologi Fakultas Kedokteran Universitas Sam Ratulangi Manado \\ Email:paai_manado@yahoo.com
}

\begin{abstract}
Emotional intelligenceis the ability to recognize one's own emotions, managing emotions themselves, motivating one self, recognizing emotions in others, managing emotions in others and motivate others. While learning achievementis the resultof a study of learning activities based on the measurement and assessment of learning outcome sin academic areas are embodied in the form of number sin there port card. When students have high emotional intelligence, it will improve learning achievement. Susceptible adolescents aged 11-16 years with astudent status, emotional intelligence is the ability to regulate one's emotional life with intelligence. The research objective was to determine the level of the general purpose of emotional intelligenceand learning achievementin students, a special purpose to know the descriptionof emotional intelligence that is about recognizing your own emotions, managing emotions yourself, motivate yourself and recognize other people's emotions, managing emotions in others, as well as motivating others, and learning achievement at the student has with an average value of report cards. The study population was Manado XI Junior High School student $\sin 2011 / 2012$. Data collection procedures using a questionnaire. The data presented in tabular form as well as analysis of the frequency distribution of cross presentation use. Conclusion: The study found that emotional intelligence is and average student achievements were.
\end{abstract}

Key Words: emotional intelligence, learning on student achievement

\begin{abstract}
Abstrak: Kecerdasan emosional adalah kemampuan seseorang untuk mengenali emosi diri sendiri, mengelola emosi diri sendiri, memotivasi diri sendiri, mengenali emosi orang lain, mengelola emosi orang lain dan memotivasi orang lain. Sedangkan prestasi belajar adalah hasil belajar dari suatu aktivitas belajar yang dilakukan berdasarkan pengukuran dan penilaian terhadap hasil kegiatan belajar dalam bidang akademik yang diwujudkan berupa angka-angka dalam rapor. Bila siswa memiliki kecerdasan emosional yang tinggi, maka akan meningkatkan prestasi belajar. Remaja dengan rentang usia 11-16 tahun yang berstatus siswa, kecerdasan emosional adalah kemampuan seseorang mengatur kehidupan emosinya dengan intelegensi. Tujuan penelitian adalah tujuan umum untuk mengetahui tingkat kecerdasan emosional dan prestasi belajar pada siswa, tujuan khusus untuk mengetahui gambaran kecerdasan emosional yakni tentang mengenali emosi diri sendiri, mengelola emosi diri sendiri, memotivasi diri sendiri dan mengenali emosi orang lain, mengelola emosi orang lain, serta memotivasi orang lain, dan prestasi belajar pada siswa yakni tentang nilai rata rata raport. Populasi penelitian adalah siswa SMP Negeri XI Manado tahun 2011/2012. Prosedur pengambilan data dengan menggunakan kuesioner. Data disajikan dalam bentuk tabel serta analisis presentasi.dan menggunakan distribusi frekuensi silang. Simpulan: Hasil penelitian didapatkan bahwa kecerdasan emosional siswa sedang dan rata rata prestasi sedang.
\end{abstract}

Kata kunci: kecerdasan emosional dan prestasi belajar pada siswa. 
Pendidikan emosi sangatlah penting karena harapan suatu bangsa terletak pada baiknya pendidikan dimasa mudanya, dan sebagai proses mengubah tingkah laku melalui latihan dan pengalaman. ${ }^{1}$ Definisi kecerdasan emosional adalah sebagai himpunan bagian dari kecerdasan sosial yang melibatkan kemampuan memantau perasaan sosial yang melibatkan kemampuan pada orang lain, memilah-milah semuanya dan menggunakan informasi ini untuk membimbing pikiran dan tindakan. ${ }^{2}$ Proses belajar yang terjadi pada siswa merupakan sesuatu yang penting, karena melalui belajar individu mengenal lingkungannya dan menyesuaikan diri dengan lingkungan disekitarnya, emosi juga mempunyai peranan penting pada siswa untuk dapat mewujudkan cita cita yang diharapkan. Pengelolaan emosi yang baik pada siswa akan menimbulkan kemauan belajar yang lebih efektif sehingga meningkatkan hasil prestasi yang baik. ${ }^{3}$ Data penelitian Wahid Muhaimin Nugroho prestasi belajar menunjukkan kategori sedang. Sedangkan kecerdasan emosional siswa menunjukkan kategori sedang sebanyak 61\%. Dari hasil penelitian Wahid Muhaimin Nugroho disimpulkan adanya hubungan yang signifikan antara prestasi belajar dengan kecerdasan emosional siswa, dalam arti semakin tinggi prestasi belajar semakin baik pula kecerdasan emosional siswa. ${ }^{4}$

\section{TUJUAN PENELITIAN}

Melakukan pengujian secara empiris untuk mengetahui gambaran tingkat kecerdasan emosional dan prestasi belajar pada siswa di SMP Negeri XI Manado.

\section{MANFAAT PENELITIAN}

Dari segi teoritis: Penelitian ini diharapkan dapat memberikanpengetahuan mengenai gambaran kecerdasan emosional dan prestasi belajar bagi dunia pendidikan dan memperkaya hasil penelitian yang telah ada. Sedangkan dari segi praktis diharapkan dapat membantu memberikan infor- masi khususnya kepada para orang tua, konselor sekolah dan guru dalam upaya membimbing dan memotivasi siswa remaja dalam mengendalikan kecerdasan emosional yang dimilikinya.

\section{TINJAUAN PUSTAKA}

\section{Kecerdasan Emosional}

Kecerdasan emosional adalah kemampuan siswa untuk mengenali emosi diri, mengelola emosi diri, memotivasi diri sendiri, mengenali emosi orang lain (empati) dan kemampuan untuk membina hubungan (kerjasama) dengan orang lain. ${ }^{5}$ Dimana orang cenderung menganut gaya-gaya khas dalam menangani dan mengatasi emosi mereka, yaitu Sadar diri adalah peka akan suasana hati mereka ketika mengalaminya dapat dimengerti bila orang-orang ini memiliki kepintaran tersendiri dalam kehidupan emosional meraka. Kejernihan pikiran mereka lain, misalnya: Mereka mandiri, yakin akan batas-batas yang mereka bangun, kesehatan jiwa bagus dan cenderung berpendapat positif akan kehidupan, Tenggelam dalam permasalahan adalah mereka orang-orang yang sering kali dikuasai oleh emosi dan tak berdaya untuk melepaskan diri, seolah-olah suasana hati mereka telah mengambil alih kekuasaan. Akibatnya mereka kurang berupaya mengendalikan atas kehidupan emosional mereka, Pasrah adalah meskipun sering kali orang-orang ini peka akan apa yang mereka rasakan, mereka juga cenderung menerima begitu saja suasana hati mereka, sehingga tidak berusaha untuk mengubahnya. ${ }^{6}$

\section{Prestasi belajar}

Prestasi belajar ditunjukkan dengan skor atau angka yang menunjukkan nilainilai dari sejumlah mata pelajaran. Belajar adalah "suatu proses usaha yang dilakukan seseorang untuk memperoleh suatu perubahan tingkah laku yang baru secara keseluruhan, sebagai hasil pengalaman sendiri dalam interaksi dengan lingkungannya". Selanjutnya Winkel juga menambahkan 
bahwa belajar adalah suatu aktifitas mental atau psikis yang berlangsung dalam interaksi yang aktif dengan lingkungan, yang menghasilkan perubahan perubahan dalam pengetahuan, pemahaman, keterampilan, dan nilai sikap. Perubahan itu bersifat konstan dan berbekas, ini menunjukkan bahwa perubahan yang terjadi karena belajar tidak timbul begitu saja, belajar lebih banyak membutuhkan kegiatan yang disadari, suatu aktifitas dan latihan latihan.

\section{METODE}

\section{Populasi dan sampel penelitian}

Populasi penelitian yang akan diteliti adalah siswa SMP Negeri XI Manado tahun 2011/2012 dan Sampel yang diambil adalah seluruh siswa kelas II SMP Negeri XI Manado tahun 2011/2012,yang berjumlah 100 siswa.

\section{Variabel penelitian}

Variabel penelitian gambaran kecerdasan emosional dan prestasi belajar pada siswa didapatkan dari Karakteristik Responden yang diambil berdasarkan Jenis kelamin, Umur, Pekerjaan orang tua, dan Tinggal dengan (orang tua, bibi, oma, saudara, tante). Kecerdasan emosional diukur dengan cara Mengenali emosi diri sendiri, Mengelola emosi diri sendiri, Memotivasi diri sendiri, Mengenali emosi orang lain Mengelola emosi orang lain dan Memotivasi orang lain. Sedangkan Prestasi belajar dilihat dari faktor-faktor sikap, tindakan yang menghasilkan rata rata nilai raport.

\section{Operasional Penelitian}

\section{Definisi Konseptual}

Siswa remaja adalah orang yang terdapat di SMP Negeri XI, siswa kelas II yang mempunyai hak mengikuti kegiatan belajar disekolah tersebut. Kecerdasan emosional adalahkemampuan siswa untuk mengenali emosi diri, mengelola emosi diri, memotivasi diri sendiri, mengenali emosi orang lain (empati) dan kemampuan untuk membina hubungan (kerjasama) dengan orang lain. Prestasi belajar adalah perubahan sikap dan tindakan yang menggambarkan pengetahuan dan ketrampilan yang diperoleh siswa, serta untuk dapat memperoleh nilai digunakan tes terhadap mata pelajaran terlebih dahulu. Hasil tes inilah yang menunjukkan keadaan tinggi rendahnya prestasi yang dicapai oleh siswa.

\section{Definisi Operasional}

Instrumen menggunakan kuesioner dengan model skala Likert. Untuk item positif penilaian bergerak dari skor 5 (sangat setuju), 4 (setuju), 3 (kurang setuju), 2 (tidak setuju), 1 (sangat tidak setuju). Sedangkan untuk item negatif penilaian bergerak dari skor 1 (sangat setuju), 2 (setuju), 3 (kurang setuju), 4 (tidak setuju), 5 (sangat tidak setuju).

Kecerdasan emosional terdiri dari mengenali emosi diri sendiri, mengelola emosi diri sendiri, memotivasi diri sendiri, mengenali emosi orang lain, mengelola emosi orang lain, memotivasi orang lain. Prestasi belajar adalah merupakan suatu proses perubahan yang terjadi dalam diri seseorang baik pengetahuan, ketrampilan dan sikap yang dilihat dari rata rata nilai rapor, yang dimiliki dari setiap siswa.

\section{Teknik pengumpulan data}

Pengumpulan data dilakukan penulis dengan melalui pengisian kuisioner di SMP Negeri XI, Manado dan nilai raport pada siswa yang bertujuan untuk mengumpulkan data tentang kecerdasan emosional dan prestasi belajar pada siswa kelas II SMP Negeri XI, Manado.

\section{Pengolahan Data dan Teknik Analisis data}

1. Cara penilaian kelas interval kecerdasan emosional

Skala penilaian dibuat dengan menggunakan kelas interval, dengan 3 langkah, langkah pertama mencari skor terbesar dan skor terkecil, langkah kedua mencari nilai rentangan (R), langkah ketiga tentukan banyaknya kelas (ditentukan 3 kelas), dan langkah keempat 
mencari nilai panjang kelas (i) dengan rumus nilai rentang $(\mathrm{R})$ dibagi jumlah banyak kelas.

$\mathrm{i}=\frac{=\text { Skor terbesar }- \text { Skor terkecil }(\mathrm{R})+1}{3}$

Setelah mendapatkan nilai panjang kelas maka hasilnya diinput dalam tiga kelas, yakni kelas rendah, sedang, dan tinggi. Nilai dimasukkan ke dalam kelas sedang jika didapatkan nilai panjang kelas yang tidak proporsional untuk ketiga kelas.

2. Cara penilaian kelas interval Prestasi Belajar

Prestasi belajar diambil dari nilai rata rata semester I siswa kelas II SMP. Kemudian nilai dibagi tiga untuk menentukan rentang yakni 7.0-8.0 (rendah), 8.1-9.0 (sedang), dan 9.1-10 (tinggi).

3. Menentukan frekuensi dengan menggunakan SPSS untuk membuat tabel tabulasi silang antara kelas interval kecerdasan emosional dengan kelas interval prestasi belajar.

4. Data tersebut dikelompokkan berdasarkan variabel penelitian dan disajikan dalam bentuk tabulasi dan kemudian dianalisis berdasarkan hasil persentase, serta disajikan dalam tabel distribusi frekuensi silang.

\section{PEMBAHASAN HASIL PENELITIAN}

\section{Karakteristik Responden}

Dari hasil penelitian yang dilakukan pada siswa kelas II SMP Negeri XI Manado dengan total 100 siswa, berdasarkan umur dan jenis kelamin laki laki dan perempuan, didapatkan umur tertinggi
13 tahun yakni 45 orang (45\%) dan umur terkecil 11 tahun yakni satu orang (1\%), dimana jumlah perempuan didapatkan sebesar 62 orang dan jumlah laki laki sebesar 38 orang. Hasil penelitian distribusi responden berdasarkan pekerjaan orang tua didapatkan adalah yang paling terbanyak buruh yakni 30 orang (30\%), dan yang paling sedikit adalah nelayan dan IRT (Ibu Rumah Tangga) sebesar tiga orang (3\%). Hasil penelitian distribusi responden berdasarkan tinggal dengan didapatkan yang paling terbanyak adalah Orang tua yakni 93 orang (93\%), dan yang paling sedikit adalah Bibi, Oma, dan Tante sebesar satu orang (1\%).

\section{Kecerdasan Emosional dan Prestasi Belajar}

Tabel 1. Kelas Interval Kecerdasan Emosional

\begin{tabular}{ccc}
\hline $\begin{array}{c}\text { Kelas interval } \\
\text { Kecerdasan Emosional }\end{array}$ & $\begin{array}{c}\text { Jumlah } \\
\text { (Orang) }\end{array}$ & \begin{tabular}{c} 
\% \\
\hline $105-125$ (Rendah)
\end{tabular} \\
\hline $126-148$ (Sedang) & 55 & 7 \\
$149-169$ (Tinggi) & 38 & 38 \\
\hline Total & $\mathbf{1 0 0}$ & $\mathbf{1 0 0}$ \\
\hline
\end{tabular}

Berdasarkan penilaian kecerdasan emosional didapatkan responden terbanyak pada interval kelas 126-148 (sedang) sebanyak 55 orang $(55 \%),{ }^{8}$ yang menurut tabel diatas, rata-rata prestasi responden sedang. Sedangkan yang paling sedikit pada kelas interval 105-125 (rendah) berjumlah tujuh orang (7\%). Jumlah responden paling sedikit terdapat pada nilai ratarata prestasi sedang dengan kecerdasan emosional rendah.

Tabel 2. Distribusi frekuensi silang kecerdasan emosional dan prestasi.

\begin{tabular}{c|c|c|c}
\hline \multirow{2}{*}{$\begin{array}{c}\text { Kecerdasan } \\
\text { Emosional }\end{array}$} & \multicolumn{3}{c}{ Nilai Rata-rata } \\
\cline { 2 - 4 } & Rendasi & $\begin{array}{c}\text { Sedang } \\
\mathbf{( 7 . 0 - 8 . 0 )}\end{array}$ & $\begin{array}{c}\text { Tinggi } \\
\mathbf{( 8 . 1 - 9 . 0 )}\end{array}$ \\
\hline Rendah & 3 & 2 & 2 \\
Sedang & 11 & 33 & 11 \\
Tinggi & 9 & 22 & 7 \\
\hline Total & $\mathbf{2 3}$ & $\mathbf{5 7}$ & $\mathbf{2 0}$ \\
\hline
\end{tabular}


begitu juga dengan nilai rata-rata prestasi tinggi dengan kecerdasan emosional rendah sebanyak dua responden $(2 \%)$.

\section{Mengenali emosi diri sendiri}

Untuk aspek mengenali emosi diri sendiri,didapatkan responden terbanyak pada kelas interval 23- 30 (tinggi) sebanyak 62 orang $(62 \%)$, jumlah responden paling banyak terdapat pada nilai rata-rata prestasi 8,1-9,0 (sedang) dengan aspek mengenali emosi diri sendiri tinggi sebanyak 37 responden (37\%). Ada pendapat yang mengatakan bahwa semakin tinggi kecerdasan seseorang maka semakin tinggi pula prestasi belajar yang didapatkan. Tetapi pada penelitian ini didapatkan hal yang berbeda ini mungkin diakibatkan karena adanya faktor faktor lain seperti: faktor dari dalam diri siswa, terdiri dari faktor fisiologis yang berkaitan dengan keadaan atau kondisi jasmani dan rohani siswa. Sedangkan faktor psikologis ditinjau dari tingkat kecerdasan siswa, sikap siswa, bakat siswa, minat siswa, dan motivasi siswa, serta kondisi psikis siswa, Faktorfaktor yang dari luar siswa meliputi faktor pengatur belajar mengajar di sekolah yaitu kurikulum pengajaran, disiplin sekolah, fasilitas belajar, dan pengelompokan siswa. Selain itu faktor-faktor sosial di sekolah yang juga mempengaruhi yaitu, status sosial siswa, interaksi guru dengan siswa. Serta faktor situasional yaitu keadaan sosial ekonomi, keadaan waktu dan tempat, dan lingkungan.

\section{Mengelola emosi diri sendiri}

Untuk aspek mengelola emosi diri sendiri, didapatkan responden terbanyak pada kelas interval 16-23 (sedang) sebanyak 58 orang $(58 \%)$. Jumlah responden paling banyak terdapat pada nilai rata-rata prestasi 8,1-9,0 (sedang) dengan aspek mengelola emosi diri sendiri sedang sebanyak 32 responden $(32 \%)$. Keterampilan mengelola emosi diri sendiri pada intinya adalah tentang bereaksi dengan suatu cara terhadap emosi yang kita hadapi dalam hidup. Kemampuan mengendalikan emosi membuat individu dapat memiliki fleksibilitas yang besar dalam emosi serta kehidupan sosial. Kemampuan ini dapat membuat individu dapat mengendalikan rangsangan sehingga dapat memaksimalkan rangsangan, lebih tabah dalam menghadapi frustasi dan godaan, mencegah dampak buruk dari hasutan orang lain, serta dapat bertindak tepat meskipun ada tekanan dari orang lain untuk melakukanhal yang sebaliknya. Kemampuan ini juga dapat membantu individu untuk membuat orang lain, tidak hanya mengurangi atau meningkatkan emosi positif, tetapi meningkatkan keinginan orang lain untuk berusaha keras dan menghadapi tantangan. Sehingga siswa dapat menghadapi tekanan pelajaran sekolah sehingga prestasi belajar siswa baik, pada intinya mengelola emosi diri sendiri berhubungan dengan prestasi belajar.

\section{Memotivasi Diri Sendiri}

Untuk aspek memotivasi diri sendiri, hasil penelitian didapat bahwa responden terbanyak pada kelas interval 21-25 (sedang) sebanyak 57 orang (57\%). Jumlah responden paling banyak terdapat pada nilai rata-rata prestasi 8,1-9,0 (sedang) dengan aspek memotivasi diri sendiri sedang sebanyak 32 responden (32\%). Kendali diri emosional adalah menahan diri terhadap kepuasan dan mengendalikan dorongan hati sehingga terciptalah suatu keberhasilan dalam berbagai bidang. Orang-orang yang memiliki keterampilan ini cenderung jauh lebih produktif dan efektif dalam hal apa pun yang dilakukan dan dikerjakan, sehingga siswa yang memiliki ketrampilan memotivasi diri sendiri akan memiliki prestasi belajar yang baik (terjadi hubungan antara prestasi belajar dengan motivasi diri sendiri).

\section{Mengenali Emosi Orang Lain}

Untuk aspek mengenali emosi orang lain, hasil penelitian didapat bahwa responden terbanyak pada kelas interval 20-25 (sedang) sebanyak 58 orang (58\%). Jumlah responden paling banyak terdapat pada nilai rata-rata prestasi $8,1-9,0$ (sedang) 
dengan aspek mengenali emosi orang lain sedang sebanyak 36 responden (36\%). Orang yang empatik lebih mampu menangkap sinyal-sinyal sosial yang tersembunyi yang mengisyaratkan apa-apa yang dibutuhkan atau dikehendaki orang lain sehingga orang lain merasa nyaman dan tenang berada di dekatnya, sehingga siswa yang memiliki ketrampilan ini memiliki suasana belajar yang nyaman di sekolah karena memiliki banyak teman yang akan mengakibatkan prestasi belajarnya baik.

\section{Mengelola Emosi Orang Lain}

Untuk aspek mengelola emosi orang lain, didapatkan responden terbanyak pada kelas interval 19-23 (sedang) sebanyak 72 orang $(72 \%)$. Jumlah responden paling banyak terdapat pada nilai rata-rata prestasi 8,1-9,0 (sedang) dengan aspek mengelola emosi orang lain sedang sebanyak 40 responden (40\%). Aspek ini merupakan keterampilan yang menunjang popularitas, kepemimpinan, dan keberhasilan antar pribadi. Orang-orang hebat dalam keterampilan ini akan sukses dalam bidang apapun yang mengandalkan hubungan yang baik dengan orang lain, sehingga siswa yang mempunyai ketrampilan ini dapat membina hubungan baik dengan antar siswa yang akan menunjang suasana belajar yang kondusif yang akan mempengaruhi prestasi belajar siswa.

\section{Memotivasi Orang Lain}

Aspek memotivasi orang lain, didapatkan responden terbanyak pada kelas interval 20-25 (sedang) sebanyak 61 orang (61\%). Jumlah responden paling banyak terdapat pada nilai rata-rata prestasi $8,1-9,0$ (sedang) dengan aspek memotivasi orang lain sedang sebanyak 33 responden (33\%). Aspek ini adalah bentuk lain dari kemampuan kepemimpinan, yaitu kemampuan menginspirasi, mempengaruhi dan memotivasi orang lain untuk mencapai tujuan bersama, hal ini erat kaitannya dengan kemampuan membangun kerja sama tim yang tangguh dan handal. Sehingga siswa dapat saling memotivasi untuk mem- bentuk kelompok belajar dalam kelas yang dapat mempengaruhi prestasi belajar.

Hasil penelitian ini sesuai dengan penelitian Wahid Muhaimin Nugrohoyang dilakukan di SMP Isriati Semarang, yang menyatakan prestasi belajar menunjukkan kategori sedang. Sedangkan kecerdasan emosional siswa menunjukkan kategori sedang sebanyak $61 \%$. Hasil penelitian Wahid Muhaimin Nugroho menyimpulkan adanya hubungan yang signifikan antara prestasi belajar dengan kecerdasan emosional siswa, dalam arti semakin tinggi prestasi belajar semakin baik pula kecerdasan emosional siswa ${ }^{4}$.

\section{SIMPULAN}

Kecerdasan emosional siswa kelas II SMPN XI Manado termasuk dalam kategori sedang,dengan rata-rata prestasi responden sedang. Kemampuan mengenali emosi diri sendiri siswa adalah tinggi dengan, nilai rata-rata prestasi (sedang). Kemampuan mengelola emosi diri sendiri, kemampuan memotivasi diri sendiri, kemampuan mengenali emosi orang lain, kemampuan mengelola emosi orang lain serta kemampuan memotivasi orang lain siswa adalah sedang, dengan nilai rata-rata prestasi (sedang). Adanya keterkaitan antara kecerdasan emosional dengan prestasi belajar siswa SMPN XI Manado.

\section{DAFTAR PUSTAKA}

1. Mustaqim, Wahib A. Psikologi Pendidikan. Jakarta: PT. Rineka Cipta, 2010.

2. Goleman D. Definisi dasar kecerdasan emosional. Kecerdasan Emosional (terjemahan) .Jakarta: PT. Gramedia Pustaka Utama,1997.

3. Syah M. Psikologi Pendidikan. Bandung: PT Remaja Rosdakarya, 2010.

4. Nugroho Muhaimin Wahid. Korelasi Prestasi Pelajar dengan Kecerdasan Emosional. [homepage on the Internet]. 2008 [cited thn Feb 5]. Available from: library.walisongo.ace.id/digilib/gdl.php ?mod=browse\&op=read\&id=jtptiaingdl-wahidmuhai-4156.) 
70 Jurnal e-Biomedik (eBM), Volume 1, Nomor 1, Maret 2013, hlm. 64-70

5. Awangga SN. Tes EQ plus. Yogyakarta: Pararaton Publishing, 2008.

6. Goleman D. Ringkasan singkat Horward Gardner, Multiple Intelligences Kecerdasan Emosional (terjemahan). Jakarta: PT Gramedia Pustaka Utama, 1997.

7. Ridwan. Ketercapaian Prestasi Belajar [homepage on the internet]. 2008 [cited year mon date]. Available from: http://ridwan202.wordpress.com/2008/0 5/03/ketercapaian-prestasi-belajar/

8. Sunarto H. Pengantar Statistika untuk penelitian:pendidikan,

sosial,komunikasi, Ekonomi, dan Bisnis. Bandung: Alfabeta, 2010. 